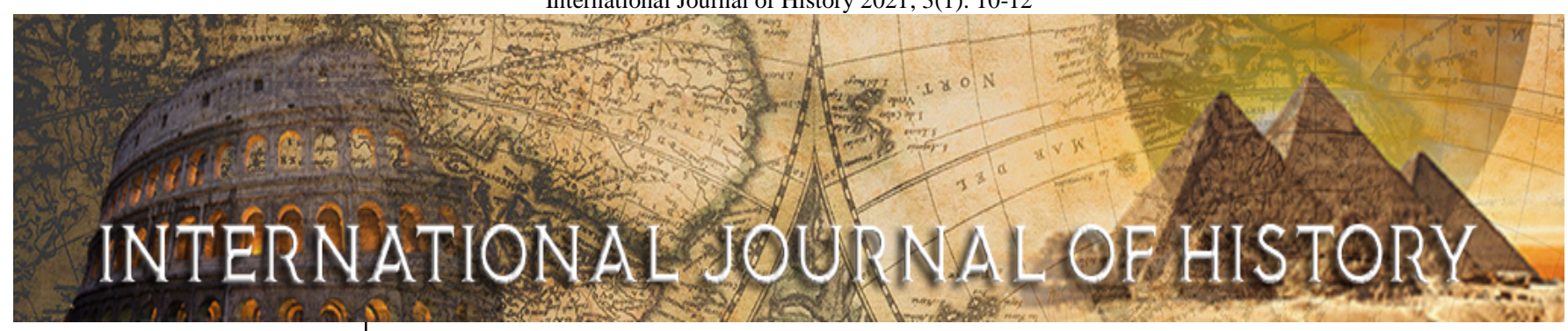

E-ISSN: 2706-9117 P-ISSN: 2706-9109 www.historyjournal.net IJH 2021; 3(1): 10-12 Received: 13-11-2020 Accepted: 19-12-2020

Ranjana Singh Post - Research Scholar Department - Ancient Indian history culture and Archeology (AICH \& ARCH) UniversityAPS University, Rewa, Madhya Pradesh, India
Corresponding Author: Ranjana Singh

Post - Research Scholar Department - Ancient Indian history culture and Archeology (AICH \& ARCH) UniversityAPS University, Rewa, Madhya Pradesh, India

\section{A Historical study on Shiva temple of Bhumara}

\section{Ranjana Singh}

\section{DOI: $\underline{\text { https://doi.org/10.22271/27069109.2021.v3.i1a.78 }}$}

\begin{abstract}
The present study focuses on the historical temple of Shiva. It is also called Bharkuleshwar Temple district of Satna. The present research paper explains the structural architecture art of the Gupta period of Bhumara. The study describes the historical significance of study area, development of the temple. The researcher has adopted a descriptive research method in the present historical study. In addition, historical methodology is adopted for observing, recording, describing, analyzing, interpreting the data and comparing the data, which is collected during the courses of research on the basis of dynastic affiliation and chronology, the temple selected for the present study is classified into three groups namely in Gupta era. The finding of the study reveals that the past ancient greatness of Shiva temple of Bhumara. Its very development temple of Gupta era.
\end{abstract}

Keywords: Shiva temple of Bhumara, architecture, sculptures

\section{Introduction}

Bhumara temple is located $12 \mathrm{~km}$. northwest from Unchehra near the hills of Khamha and Mohnna. It is about 40 Kilometers in Satna District (MP).There is a Shiva temple was discovered by R.D. Banergy in 1920.

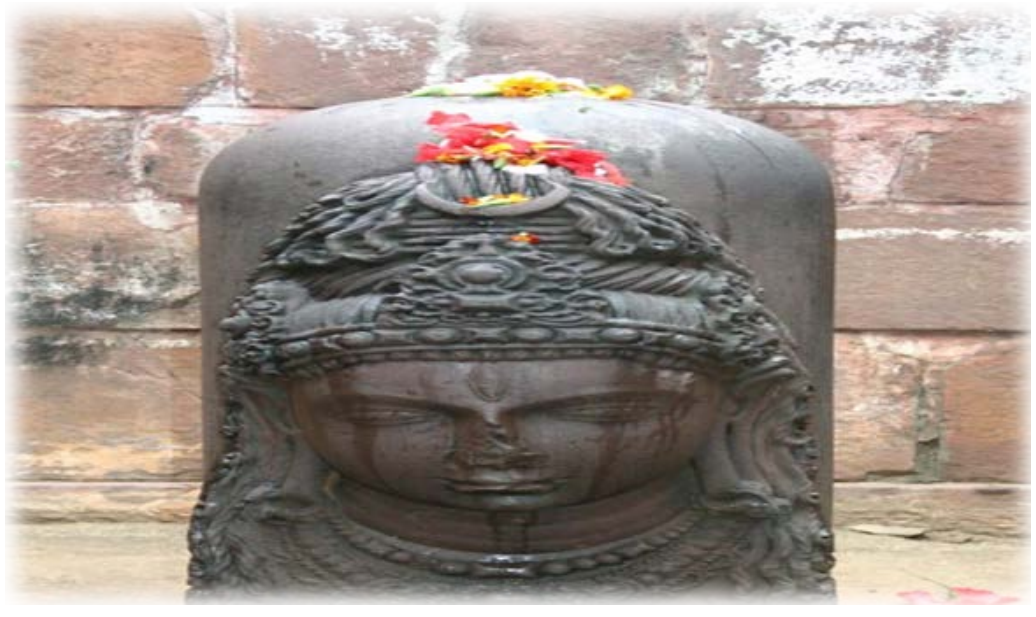

Bhumara temple is also called Bhubhara or Bharkuleswar. It is built in Gupta dynasty during $5^{\text {th }}$ or $6^{\text {th }}$ century. The Bhumara temple is made of red stone found in kaimor hills. It seems the temple has a square plan with sanctum and Mandapa. Both sides of it two smaller shrines on the flanks on the enterance steps. It includes a decorated enterance the sanctum Flanked by Ganga and Yamuna Goddesses and intiricately carved Sculptures. This temple is called Ekmukha Linga. The temple reliefs include those for Durga, Ganesha, Brahma, Vishnu, Yama, Kubera, Kartikeya, Surya, Kama and others. The sculpture found midst Bhumara temple ruins. This temple stands on an approximately 1.4metres (4ft 7) in high platform. Stairs lead to the platform, and the steps are 11.25 feet $(3.43 \mathrm{~m}$.) long and 8.43 feet $(2.57 \mathrm{~m})$ in breadth. On the top of the platform, are two concentric chambers with a square plan? The smaller inner square is a windowless Garbhgriha with a 15.17 feet $(4.62 \mathrm{~m})$ side. The outer Square has 35 feet (11) in length and same in width. The space between the inner sanctum 
chamber and the outer side built an enclosed space for circumambulation. The steps leading to the sanctum are flanked by two smaller platforms about 8.17 feet $(2.49 \mathrm{~m})$ by 5.67 feet $(1.73 \mathrm{~m})$, each with a small shrine. The temple likely had three entrances. The Mandapa was 29.83 feet $(9.09 \mathrm{~m})$ by 13 feet $(4.0 \mathrm{~m})$. The ruined structure that has been viewable since $20^{\text {th }}$ century is the inner sanctum with its intricate carvings the platforms, the stairs and remant walls. The roof of the temple was simple. Two carved Jambs lintel and a sill consist of the sanctum door.

Ganga godess is right standing on her Vahana - the Makara, Yamuna godess is left side standing on her Vahana - a tortoise. Above these goddesses are three parallel bands of carvings. But both are in broken condition. Some walls and statue has been broken as well as ruined parts of mandapas. Most of the part is not in good condition of this temple.

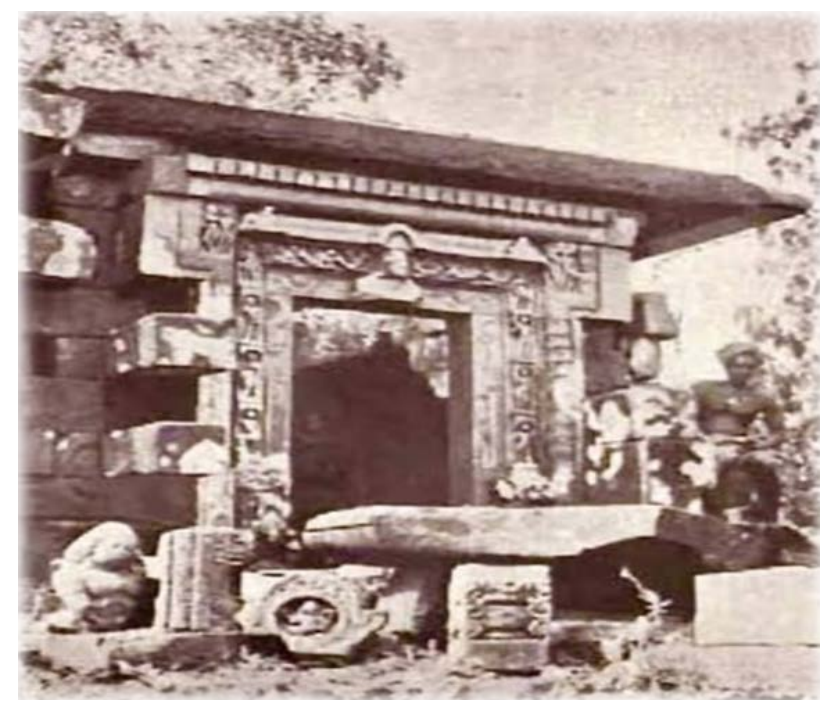

History of Bhumara Temple -

Bhumara temple is also called Bhubhara or Bharkuleshwar, is a $5^{\text {th }}$ or $6^{\text {th }}$ century B.C. This temple site is dedicated to shiva. The early history of the site is not known. Archaeologist Cunningham visited the Bhumara site and he mentioned in his report about standing stone during his 1873 -1874 tour of the central Indian region. He found the stone and inscription which was related to Bhumara temple, then he published, but he missed the temple that was the most of the part covered by forest of Shrubs. John Faithfull Fleet translated the inscription in 1888, and it has been mentioned about two kings named Hastin and Sarvantha. It is believed the pillar inscription also described the boundary between their kingdoms and gave an inscription date per ancient Indian calendar that equals 484 C.E.

In 1919-1920 the archaeolical Survey of India sent a sketch Wartekar who was an artist and a photographer Joglekar together to revisit the site. According to them the local villager claims of many temples of plateau and northern face of hills. Bhumara temple has been found by them in dense forest during search. They reported about it; and mentioned it to be small single cell structure with a slab roof near an unusual soil mound, and that the temple's door was "' magnificently carved', In the first report they have been giving that stones were sticking out of the temple was originally much bigger. They mentioned that broken pillars and ruins surrounded it. The Archaeological Survey of India resent a larger team, excavated the mound discovered numerous sculptures among these were a Chaitya - window shaped panel with a circular - medallion and the sculpture of Ganesha, jumbled remains of Mandapa and some parts of temple was undertaken in early 1920s. During this cleaning many more sculptures and their fragments, pillar fragments, lintels, Jambs with a number of images were found.

Here is the most important symbol of the sun god images, and have shown that the paramount God of the Jatts in central Asia was the sun, which retained its position even in India where the images of this god were made in the same from and dress as these people themselves wore. The long coat, the sword, the boots, and the sunflower were used on these images have been found from Mathura to Bengal and the famous Bhumara temple of the Guptas is well Known. Here too the Surya image foreign symbols. We find the sunflower in the temples of the sun god in India. A very important instance of this type has been described by Kalidasa. The figure is about two and half feet high and it has been made of basalt - stone of bluish colour. In this figure, the sun god has worn a cap like head dress, from underneath which curls of hair are descending on each shoulder; a short necklace, apparently of beads with a rectangular bar in the centre, plain bracelates and a long tunic, similar to that of the surya images found in the Gupta temple of Bhumara. This type of dress has been seen in Kushana period. In each of the two hands there is a lotous stalk, rising just about the shoulders and teeming in a bunch of lotuses, unlike a single lotus as depicted in the later images. The waist is tied round by a belt with two hanging tassels from the study in the centre. Along With the left side, there is sword kept in position by means of a strap. The 1500 year old temple is now part of the Allahabad and museum adding to its exceptional historical and cultural value. The condition of the temple is not good at the present time. The temple is under the survey of India but it has not been well preserved and conserved. The art of the Gupta Period is marked by deep spiritual quality and a vision which tries to record the higher and deeper truths of life. While the early Gupta period shows an emphasis.

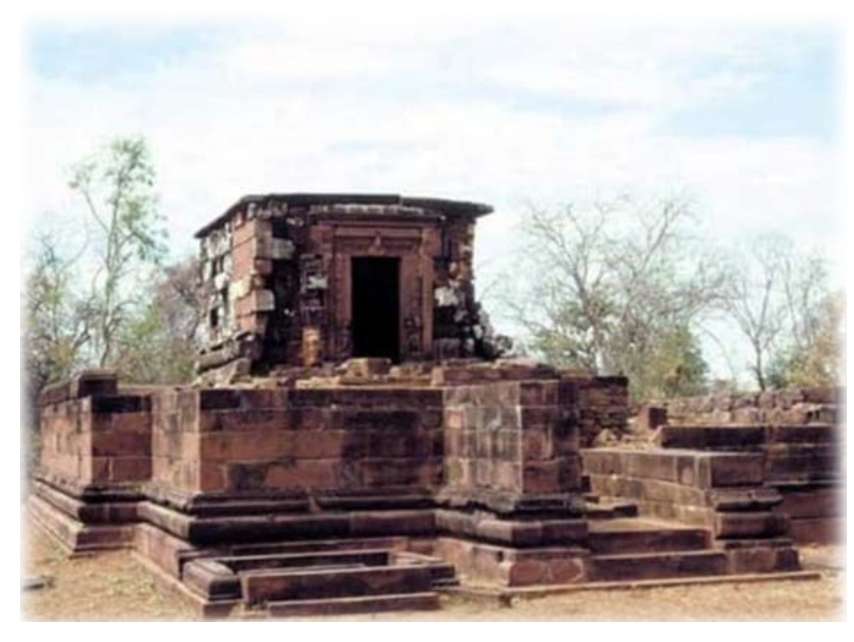

Gupta temple style -

According to Dr. Naval Viyogi considers the style of temple of Bhumara to be that of Bharsiva Nagas - During the Gupta period $2^{\text {nd }}$ century BC., The setting up of sanctuaries for the images of gods shows. The devagrahas of the pre - Christian centuries which have been excavated are in an extremely fragmentary state. But it has been built by perishable materials they apparently afforded little scope for architectural Principles. It was in the Gupta era that building 
with lasting materials began, such as dressed stone and brick. It is believed the Gupta period was the golden age for Indian architecture. During the Gupta age used two major styles evolved.

\section{Methodology -}

The methodology adopted for the study was observation and interview method. The Bhumara temple was visited randomly 2 times and local public were interviewed each time on the aspects like challenges faced by the temple and the opportunities for improvement. The observation method was adopted as it suits best in this situation.

\section{Architecture -}

The architecture of the temple is so massive that it is clearly visible from different areas in the destination. The temple has been made in square shape plan with a sanctum and Mandapa. Most of the part of this temple in ruins condition, enough of the temple structure and artwork has survived for researcher's studies. The temple architecture is the best example of Gupta age. It included an enclosed concentric Pradakshina path like other early Gupta period Hindu temples, it includes a decorated entrance to the sanctum flanked by Ganga and Yamuna goddesses, and intricately carved sculptures. This temple is called Ekmukhi Linga. Many deities include like Mahishasurmardini (Durga), Ganesha Brahma, Vishnu, Yama, Kubera, Kartikeya, Surya, Kama and others.

\section{Conclusion-}

From the above studies it has been concluded that the Bhumara temple hold an important and significant part in the history of Satna. It has great heritage value it comes under the category of built heritage. Bhumara temple face some major problems in present Scenario which are not good condition. The Bhumara temple has certain shortcomings which should be covered by dense forest. It should be viewed as an important tourist destination as well as it is attracting large number of tourists from international market also. It should bring some amendments in the way the present scenario is going on and at the same time challenge for Madhya Pradesh government. It's should be more care of this temple.

\section{References -}

1. Bhartiya Murti Shastra - Dr. N.P Joshi, 364.

2. Hardy Adam. "Nagara Temple Forms: Reconstructing Lost Origins, "Journal of History An Social Sciences, 2014.

3. Swati Mitra. Temples of Madhya, Godernath, 40-41.

4. Bhumara (Bhumara) Shiva temple viewed from south, Gupta Dynasty, India, Ca. $5^{\text {th }} 6^{\text {th }}$ century ADC Krishna Gairola, University of Washingon, 1975.

5. ABC. "Bhumara temple" archaeological survey of India, Bhopal Circle.

6. ABC. Radhakumud Mookerji. The Gupta Empire. Motilal Banarsidass, ISBN: 978-208-0440-1, 1959, 146.

7. George Michell. 1988;39:95.

8. Kapila Vatsyayan. The Cultural Heritage of India: the arts RMIC, ISBN: 978-81-87332-48-0, 2006, 428-432. 